\title{
SIGNIFIKANSI GAMBAR TERHADAP PEMAHAMAN TEKS INSTRUKSI BAHASA INGGRIS PADA PENDIDIKAN VOKASI
}

\author{
Mahlil* \\ Politeknik Negeri Lhokseumawe \\ Tanzir Masykar \\ Akademi Komunitas Aceh Barat
}

\begin{abstract}
One of the skills vocational education students must master in English courses is understanding the language of instruction or procedures in English. A total of 24 vocational education students at the Politeknik Negeri Lhokseumawe participated in filling out the questionnaires distributed online. Data were collected using the convenience sampling technique for two weeks from the date of August 26, 2020 until September 9, 2020. The data were analyzed qualitatively using the Miles and Huberman model. Data analysis consists of four stages, extensive coding, pattern coding, distilling and making propositions. The results showed that the majority of vocational education students at PNL were visual learners. The inclusion of pictures in the English instruction material is very helpful in understanding the text of the instructions given. Students prefer English instruction materials that are equipped with pictures rather than just pictures or just text. Students also use google translate to understand unfamiliar words to understand English instruction texts.
\end{abstract}

\section{Keywords:}

English, Language Instruction, Picture Signifiance, Vocation

\begin{abstract}
Abstrak
Salah satu kemampuan yang harus dikuasai oleh mahasiswa pendidikan vokasi dalam mata kuliah Bahasa Inggris adalah memahami bahasa instruksi atau prosedur berbahasa Inggris. Sebanyak 24 mahasiswa pendidikan vokasi pada kampus Politeknik Negeri Lhokseumawe berpartisipasi mengisi kuesioner yang disebarkan secara daring. Pengambilan data menggunakan the convenience sampling technique selama dua minggu dari tanggal 26 Agustus 2020 sampai 9 Sepetember 2020.Data dianalisis secara kualitatif dengan menggunakan model Miles dan Huberman. Analisa data terdiri dari empat tahap, extensive coding, pattern coding, distilling and making propositions. Hasil penelitian menunjukkan bahwa mayoritas mahasiswa pendidikan vokasi di PNL adalah pembelajar visual. Penyertaan gambar pada materi instruksi berbahasa Inggris sangat membantu memahami teks instruksi yang diberikan. Siswa lebih memilih materi instruksi berbahasa Inggris yang dilengkapi dengan gambar daripada hanya gambar atau hanya teks saja. Mahsiswa juga menggunakan bantuan google translate dalam memahami teks instruksi Bahasa Inggris yang sulit dipahami.
\end{abstract}

Kata Kunci:

Bahasa Instrucksi, Bahasa Inggris, Sigifikansi Gambar, Vokasi

DOI: $10.38038 /$ vocatech.v2i1.50

Received: 03 October 2020 ; Accepted: 08 October 2020 ; Published: 15 October 2020

\section{*Corresponding author:}

Mahlil, Dosen Bahasa Inggris Teknik Informatika, Jurusan Teknologi Informasi dan Komputer, Politeknik Negeri Lhokseumawe, Jalan Banda Aceh-Medan KM 280,3, Buket Rata, Mesjid Punteut, Blang Mangat, Lhokseumawe, Aceh.

Email: mahlil@pnl.ac.id 


\section{PENDAHULUAN}

Salah satu kemampuan Bahasa Inggris yang wajib dikuasai oleh mahasiswa vokasi adalah kemampuan memahami instruksi tertulis dalam Bahasa Inggris. Instruksi tertulis ini dapat berupa manual dan petunjuk cara mengoperasikan alat atau cara merangkai peralatan kerja yang ditulis dalam Bahasa Inggris. Banyak peralatan mesin atau instruksi penggunaan peralatan ditulis dalam Bahasa inggris dikarenakan banyaknya peralatan teknik diimpor dari luar negeri. Oleh karena itu mahasiswa vokasi perlu menguasai kemampuan memahami teks instruksi dalam Bahasa Inggris agar bisa memahami manual dan buku petunjuk penggunaan peralatan teknik. Ketika nantinya mereka terjun ke lapangan kerja, mahasiswa vokasi diharapkan mampu memahami manual operasi peralatan yang akan mereka gunakan meskipun hanya tersedia dalam Bahasa Inggris.

Namun demikian banyak mahasiswa pendidikan vokasi mengalami kendala dalam memahami teks instruksi bahasa Inggris ketika mengikuti perkuliahan. Pengalaman guru vokasi di Politeknik Negeri Lhokseumawe mendapati bahwa kebanyakan siswa mengalami kesulitan memahami istilah-istilah Bahasa Inggris pada materi instruksi berbahasa Inggris. Untuk membantu meningkatkan pemahaman siswa terhadap teks instruksi dalam Bahasa Inggris, guru dapat menyertai setiap instruksi dengan gambar yang relevan. Tama (2014) menemukan hubungan yang signifikan antara penggunaan gambar dan kemampuan belajar kosakata Bahasa Inggris pada siswa sekolah dasar sementara Widyaningrum (2014) menemukan efek positif penggunaan gambar pada kemampuan berbicara pada siswa sekolah menengah pertama. Sedangkan istilah sulit dan tidak familiar dapat dicari tahu melalui aplikasi google translate. Aplikasi google translate memiliki beberapa kelemahan berupa tidak adanya konkordansi, derivasi kata yang tidak tepat, dan kesalahan pada frasa nominal (Sa'diyah, 2014). Namun, mahasiswa tetap memiliki persepsi positif terhadap aplikasi google translate dalam membantu mereka memahami teks berbahasa Inggris (Maulida, 2017).

Pada kurikulum pendidikan vokasi, salah satu kompetensi khusus untuk mata kuliah Bahasa Inggris adalah kemampuan memahami manual instruksi berbahasa Inggris. Pada prodi informasi teknologi informasi misalnya, mahasiswa dituntut untuk memahami instruksi pemasangan jaringan internet kabel maupun nirkabel yang berbahasa Inggris. Bahasa instruksi pada manual biasanya menyertakan gambar sebagai visualisasi bantuan dari kalimat instruksi. Namun, praktik selama ini ditemukan guru jarang menggunakan gambar sebagai media bantu untuk memahami instruksi berbahasa Inggris.

Oleh karena itu penelitian ini bertujuan untuk mengetahui signifikansi gambar dalam membantu mahasiswa memahami teks instruksi Bahasa Inggris. Bagaimana siswa memanfaatkan gambar untuk memahami teks instruksi Bahasa Inggris juga akan dibahas pada penelitian ini. Di samping gambar, strategi siswa menggunakan aplikasi web google translate sebagai alat untuk membantu memahami teks instruksi juga akan disinggung pada penelitian ini.

\section{STUDI PUSTAKA}

Bahasa Inggris adalah salah satu mata kuliah umum wajib di perguruan tinggi pendidikan vokasi. Bahasa Inggris pada Pendidikan vokasi menitikberatkan pada kemampuan praktis seperti kemampuan memahami perintah dan mengutarakan pendapat dalam Bahasa Inggris. Masykar and Nurrahmi (2020) menemukan bahwa salah satu alasan peserta didik mendaftar di Pendidikan vokasi adalah karena perguruan tinggi vokasi mengajarkan kemampuan praktis dibandingkan teoritis. Pentingnya konten praktis pada Pendidikan vokasi mendorong para pendidik untuk menyusun materi perkuliahan yang sesuai dengan kebutuhan vokasi. Tidak terkecuali mata kuliah Bahasa Inggris (Masykar, 2019). Penyusunan materi Bahasa Inggris yang praktis ini dapat dirancang dengan memepertimbangkan gaya belajar siswa.

Secara psikologis manusia memiliki tiga gaya belajar, auditori, visual dan kinestetik atau yang sering disebut sebagai gaya belajar sensori (De Porter \& Hernacki, 2000). Gaya belajar auditori adalah gaya belajar yang bertumpu pada pendengaran sebagai media penyerapan dan pemahaman suatu informasi dan ilmu. Gaya belajar visual adalah gaya belajar yang memanfaatkan media visual seperti gambar sebagai alat bantu penerimaan informasi. Gaya belajar kinestetik adalah gaya belajar yang mengandalkan gerak 
motorik untuk memahami suatu informasi. Mengakomodir berbagai gaya belajar siswa dalam materi pembelajaran tentunya akan memotivasi dan meningkatkan pengalaman belajar siswa. Bire, Geradus, and Bire (2014) menemukan hubungan korelasi yang signifikan antara gaya belajar siswa terhadap prestasi belajar siswa dengan tingkat persentase yang bervariasi. Mereka menemukan peningkatan prestasi belajar sebanyak $26 \%$ untuk gaya belajar visual dan kinestetik. Oleh karena itu, penyertaan gambar dalam pembalajaran diharapkan membantu visual lerners mendapatkan pembelajaran maksimal dari meteri yang diberikan.

Pembelajaran Bahasa Inggris tentunya juga harus mampu mengakomodir tipe siswa tertentu sehingga proses penyampaian ilmu terlaksana dengan maksimal. Mata kuliah Bahasa Inggris sebenarnya dapat memanfaatkan ketiga gaya belajar yang dikemukakan oleh De Porter and Hernacki (2000). Penggunaan audio dalam materi Bahasa Inggris bermanfaat untuk skill listening, penggunaan gambar dapat meningkatkan retensi hafalan kosakata Bahasa Inggris, sedangkan partisipasi motorik berupa gerakan dapat membantu siswa memahami makna suatu kata kerja. Tama (2014) menemukan siswa yang belajar kosakata Bahasa Inggris dengan bantuan gambar memiliki ketertarikan dan daya ingat yang lebih kuat daripada siswa yang belajar kosakata hanya dengan tulisan.

Wright (1989) menyarankan agar sebelum memilih menggunakan gambar aga guru perlu memastikan bahwa penggunaan gambar sudah memenuhi 5 kriteria kelayakan penggunaan gambar.

1. Mudah untuk dipersiapkan. Apabila keberadaan gambar membutuhkan sampai berjam-jam mempersiapkan tentunya akan menghabiskan waktu. Namun bisa dipertimbangkan apabila materi tersebut dapat digunakan untuk beberapa kelas.

2. Kemudahan penggunaan di kelas. Gambar yang digunakan haruslah digunakan ketika pembelajaran di dalam kelas. Adan sulit digunakan sebaiknya tidak menggunakan gambar.

3. Menarik bagi siswa dan guru. Gambar haruslah yang menarik bagi siswa dan guru. Jika tidak menarik tentunya gambar itu tidak ada makna untuk digunakan di dalam kelas.

4. Bermanfaat dan otentik. Gambar juga memberi kontribusi dan nilai tambah untuk pengalaman belajar bahasa

siswa.Penggunaan gambar juga harus memberikan nilai otentik dalam penggunaan Bahasa Inggris. Artinya gambar tersebut benar-benar digunakan dalam kehidupan nyata.

5. Membantu penggunaan bahasa. Penggunaan gambar juga harus memberi kontribusi dari segi pengalaman belajar bahasa Inggris.

Penggunaan gambar untuk materi perkuliahan bahasa instruksi pada pendidikan vokasi sudah memenuhi kriteria yang disebutkan oleh (Wright). Meskipun membutuhkan persiapan lama penggunaan gambar pada materi bahasa instruksi akan memberi nilai tambah dalam pengalaman belajar siswa. Oleh karena itu materi Bahasa Inggris perlu menyertakan gambar untuk meningkatkan pemahaman siswa. Penggunaan gambar tentunya harus mewakili teks instruksi yang diberikan. Harmer (2007) menyarankan agar gambar yang digunakan harus memperhatikan level kemampuan siswa dan terlihat jelas. Gambar yang digunakan dapat berupa gambar besar ditempel di dinding, gambar kartu, ilustrasi dan foto. Dengan menggunakan gambar, motivasi dan ketertarikan akan partisipasi belajar siswa akan meningkat (Wright, 1989).

Manfaat penggunaan gambar sebagai media bantu dalam pembelajaran Bahasa Inggris sudah banyak ditemukan pada penelitian-penelitian sebelumya. Widyaningrum (2014) menemukan bahwa gambar dapat meningkatkan kemampuan siswa berkomunikasi dalam Bahasa Inggris. Perbandingan antara nilai pre-test dan post-test untuk kelompok eksperimen dan kelompok kontrol menunjukkan bahwa nilai speaking post-test untuk kelompok eksperimen lebih tinggi dibandingkan nilai post-test kelompok kontrol. Pada penelitian lain, Tama (2014) menguji pengaruh gambar akan motivasi dan kemampuan mengingat kosakata Bahasa Inggris pada siswa sekolah dasar. Siswa yang belajar kosakata Bahasa Inggris dengan menggunakan gambar ternyata lebih tertarik untuk belajar dan mampu mengingat kosakata lebih baik daripada siswa yang belajar kosakata tidak menggunakan gambar. Ketertarikan siswa terlihat dari partisipasi antusias siswa ketika ditanya kosakata yang diajarkan guru.

Hestri (2013) sebelumnya juga menemukan manfaat penggunaan gambar di bidang writing terkhusus untuk recount text. Penggunaan picture 
word inductive model pada kelas writing terhadap mahasiswa semester 6 juga dapat meningkatkan kemampuan berpikir kritis dan pengalaman baru menulis (Rosyada, 2018). Siswa yang belajar writing dengan bantuan gambar mengalami peningkatan kemampuan writing dibandingkan siswa kontrol. Saputro (2013) mencoba membandingkan pemahaman siswa mengenai preposition setelah mendapat pembelajaran dengan bantuan ilustrasi gambar. Nilai post-test siswa ditemukan 30\% lebih tinggi dibandingkan nilai pretest. Artinya pembelajaran preposition akan lebih efektif jika diajarkan dengan bantuan gambar. Bahasa instruksi sangat erat kaitannya dengan preposition karena berkaitan dengan letak dan tempat. Mahasiswa pendidikan vokasi bisa saja mendapatkan instruksi perintah untuk mengarahkan suatu benda ke tempat atau arah tertentu.

\section{METODE}

Penelitian ini menggunakan open-ended dan close-ended questions, namun metode pengumpulan datanya tidak melalui wawancara, tapi melalui kuesioner yang disebarkan secara daring menggunakan google form. Pertanyaan pada kuesioner dibagi atas motivasi mahasiswa dalam usaha memahami teks instruksi baik yang bergambar maupun tidak, pemahaman mahasiswa dari prosedur bacaan, kebutuhan gambar dalam sebuah prosedur dalam bahan ajar dosen, tahapan awal yang dilaukan mahasiswa bila menjumpai teks berbahasa Inggris yang dilengkapi gambar pendamping, keakraban dengan istilah-istilah TIK berbahasa Inggris, pentingnya gambar, dan alat penerjemah yang digunakan mhasiswa dalam menerjemahkan teks berbahasa Inggris. Populasi penelitian ini adalah mahasiswa vokasi Politeknik Negeri Lhokseumawe jurusan Teknologi Informasi dan Komputer (TIK), dan sampel yang diambil adalah mahasiswa tingkat 2 jurusan TIK sebanyak 24 mahasiswa. Populasi dan sampel ini diambil berdasarkan pertimbangan bahwa mereka telah belajar di Pergururuan Tinggi Vokasi selama dua semester dan sudah mengalami pembelajaran yang menggunakan bahan ajar berbahasa Inggris dari msing-masing dosen mereka. Sampel data diambil dengan metode convenience sampling technique selama dua minggu dari tanggal 26 Agustus 2020 hingga tanggal 9 September 2020.

Data dianalisis secara kualitatif menggunakan model Huberman, Miles, and Saldana (2014). Proses analisa dimulai dengan pengumpulan data, kondensasi data dan presentasi data. Houghton, Murphy, Shaw, and Casey (2015) menjelaskan lebih jauh model ini dalam empat tahap, pengkodean ekstensif, pengkodean pola, penyaringan dan membuat proposisi. Pengkodean ekstensif dilakukan dengan mengklasifikasi jawaban peserta secara garis besar namun belum spesifik untuk dikemabangkan secara induktif. Pengkodean pola dikerjakan untuk melihat polapola bermakna yang mungkin muncul dari data yang dikumpulkan. Data kemudian dilakukan peyaringan untuk menghubungkan pola-pola yang ditemukan dari hasil penelitian dan pada tahap akhir kesimpulan disintesis dari pola-pola yang dihasilkan.

\section{HASIL DAN PEMBAHASAN}

\section{A. Motivasi Mahasiswa dalam usaha Memahami Instruksi Bahasa Inggris}

Membahas mengenai kemandirian mahasiswa untuk memahami instruksi Bahasa Inggris merupakan langkah awal agar penelitian ini dapat dikatakan reliable. Motivasi mahasiswa berpengaruh pada tingkat komprehensi membaca sebuah bacaan. Motivasi adalah dorongan psikologis dan lingkungan yang berefek pada sikap untuk mendapatkan atau melakukan perubahan dalam diri manusia, dan dalam konteks motivasi belajar adalah keinginan diri dan dukungan faktor eksternal untuk menyerap intisari dari proses belajar (Hidayah \& Hermansyah, 2016). Hasil tingkat kemandirian mahasiswa dalam memahami teks bacaan dapat dilihat di bagan berikut ini:

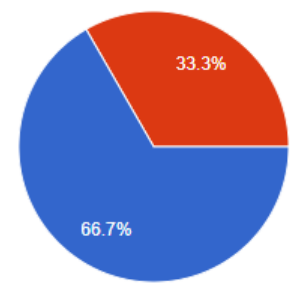

Mencoba memahami sendiri Menunggu penjelasan dosen yang bersangkutan

Gambar 1: Motivasi Mahasiswa dalam Memahami Bacaan

Dari gambar diatas terlihat $66,7 \%$ mahasiswa berusaha memahami teks secara mandiri, artinya 
adanya dorongan internal mahasiswa dalam memahami terlebih dahulu makna bacaan berbahasa Inggris sebelum mendapat penjelasan dari dosen. Dengan adanya motivasi tersebut, diharapkan mahasiswa akan lebih mampu menyerap setiap makna dalam bahasa Inggris ketika dijelaskan oleh dosen. Sebaliknya, ada sekitar $33,3 \%$ mahasiswa yang tidak termotivasi untuk membaca teks berbahasa Inggris dan memilih untuk menunggu penjelasan dari dosen.

\section{B. Pemahaman Prosedur}

Pemahaman prosedur disini maksudnya adalah bagaimana mahasiswa dapat memahami instruksi ataupun langkah-langkah pengerjaan sesuatu yang ditulis dalam bahasa Inggris. Instruksi yang diberikan adalah instruksi yang sesuai dengan bidang mereka yaitu masalah Teknologi Informasi dan Komputer. Langkah-langkah cara pengerjaan jaringan WiFi ditulis dalam bahasa Inggris tanpa dilengkapi dengan judul dan gambar. Dari hasil kuesioner, hasil yang bisa disimpulkan terbagi tiga, yaitu, paham secara umum, paham secara mendetail, dan tidak paham isi. Dari 24 responden, 17 mahasiswa memahami secara umum yaitu dengan memberi respon jawaban "cara memasang $W i F i ", 5$ orang memahami secara detail, seperti jawaban:

" tahap-tahap dari pemasangan router sampai mengatur konfigurasi wireless dan router agar wifi bisa digunakan"

"Cara setting jari[n]gan wifi di PC menggunakan konfigurasi PPPoE di web browser"

Sementara dua responden tidak memahami konten apa yang diberikan. Dari sini dapat disimpulkan bahwa, sebagian besar mahasiswa bisa memahami secara umum tentang teks yang diberikan, namun untuk kemampuan memahami secara terperinci perlu ditingkatkan lagi.

\section{Kebutuhan Gambar di setiap Prosedur}

Mengenai perlu tidaknya gambar-gambar ilustrasi yang mendampingi bacaan berbahasa Inggris, maka bisa dilihat bagan dari tanggapan responden di bawah ini.

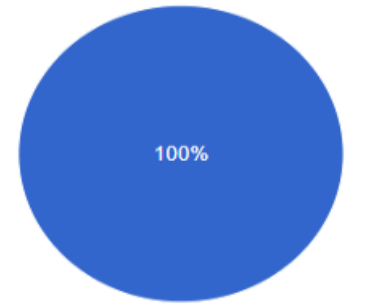

Gambar 2: Pengaruh Gambar terhadap Pemahaman Mahasiswa terhadap Bahasa Inggris

Dari gambar diatas terlihat jelas bahwa keberadaan gambar disamping teks prosedur dirasa sangat perlu oleh semua responden atau mahasiswa dan mereka merasakan bahwa gambar dapat menambah pemahaman terhadap bacaan berbahasa Inggris. Jika dilihat dari persentase, diperoleh nilai mutlak yaitu sebanyak 24 responden $(100 \%)$ setuju bahwa gambar dapat memberi mempertajam pemahaman sebuah teks dalam bahasa Inggris. Mahasiswa mendapat visualisasi terhadap mengenai bacaan yang mengandung langkah-langkah kegiatan ataupun pekerjaan.

\section{Tahapan Awal dalam Memahami Bacaan Berbahasa Inggris}

Dalam memahami bacaan berbahasa Inggris, penulis ingin mengetahui apa langkah awal dari mahasiswa dalam memahami sebuah teks prosedur berbahasa Inggris. Mahasiswa diberikan pertanyaan jika mereka melihat sebuah prosedur dalam bahasa Inggris, apa hal yang pertama mereka lihat; gambar, tulisan, atau keduanya. Hasilnya dapat dilihat dari diagram dibawah ini.

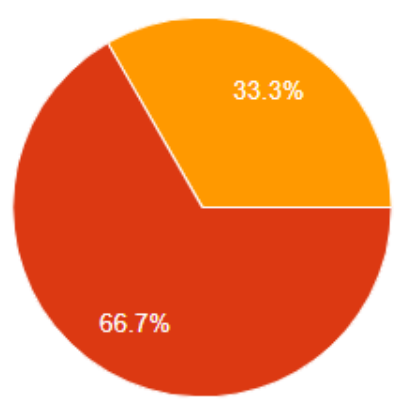

Gambar 3: Tahap Awal dalam Memahami Bacaan Berbahasa Inggris 
Diagram diatas menunjukkan bahwa mayoritas mahasiswa melihat gambar sebagai langkah awal untuk memahami teks prosedur berbahasa Inggris yaitu sebanyak $66.7 \%$. Sebanyak 8 mahasiswa $(33,3 \%)$ melihat gambar dan tulisan sekaligus. Temuan unik ditemukan bahwa tidak ada seorangpun yang memulai langkah pemahaman bahasa Inggris dengan cara membaca tulisan sebagai langkah awal. Hal ini dapat dipahami bantuan visual menarik perhatian mahasiswa sebagai alat bantu memahami teks berbahasa Inggris.

Meskipun $66.7 \%$ responden menjawab bahwa mereka membutuhkan gambar saat sebagai langkah awal, hal tersebut bukan semata-mata mereka tidak membutuhkan penjelasan teks lagi.
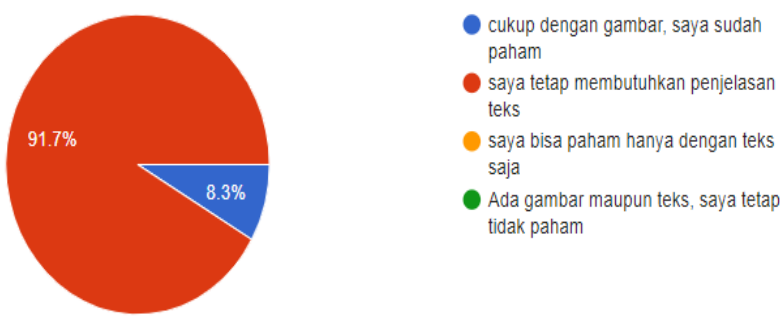

Gambar 4: Kebutuhan Teks penyerta gambar

Dari diagram diatas terlihat bahwa 22 mahasiswa (91.7\%) sepakat bahwa mereka tetap membutuhkan teks penyerta gambar walaupun berbahasa Inggris. Hanya 2 mahasiswa ( 8,3\%) yang tidak membutuhkan teks lagi untuk memahami sebuah rangkaian proses yang ditampilkan. Tidak seorang pun yang menjawab bahwa mereka paham hanya dengan melihat teks saja dan tidak ada yang menjawab pula bahwa mereka tidak mengerti sama sekali meskipun dilengkapi dengan gambar dan teks berbahasa Inggris.

\section{E. Keakraban dengan Istilah-Istilah Teknologi Informasi Berbahasa Inggris}

Dunia teknologi informasi (TI) berkembang begitu pesat. Perkembangan tersebut memunculkan istilah-istilah baru yang berbeda dengan bahasa sehari-hari. Dunia TI berkembang seiring dicanangkan revolusi industri 4.0 di berbagai benua, termasuk benua Amerika dan Eropa, dan sudah pasti muncul istilah-istilah baru dalam Bahasa Inggris di dunia TI. Berikut gambaran keakraban istilah-istilah TI berbahasa Inggris terhadap mahasiswa vokasi jurusan TIK. Gambaran ini menggunakan skala Likert 1-5; sangat tidak terbiasa, tidak terbiasa, normal, terbiasa, sangat terbiasa.

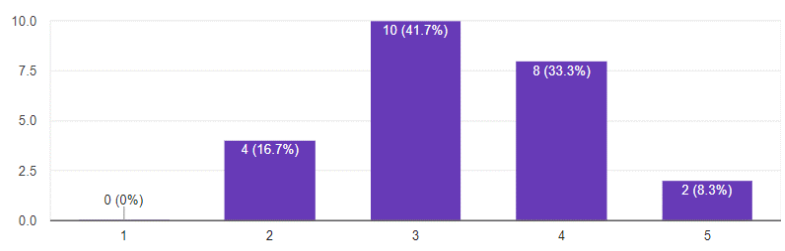

\section{Gambar 5: Skala Likert Keakraban Istilah Bahasa} Inggris bagi Mahasiswa Vokasi TIK

Dari diagram diatas tergambarkan bahwa mayoritas mahasiswa vokasi (10 responden) berada di posisi normal, artinya antara terbiasa dan tidak terbiasa. Namun 10 responden yang lain berada berada di skala 4 dan lima dimana 8 mahasiswa terbiasa dan dua lagi sangat terbiasa dengan istilahistilah TIK berbahasa Inggris. Hanya 4 orang yang memilih tidak terbiasa dengan istilah-istilah TIK berbahasa Inggris dan tidak ada yang memilih 'sangat tidak terbiasa'.

\section{F. Pentingnya Gambar Menyertai Teks Berbahasa Inggris Menurut Mahasiswa}

Di perguruan tinggi, kita diharapkan untuk mencari buku teks kita dan menghafal kata demi kata berbahasa Inggris yang terkadang cara yang kurang tepat. Mahasiswa adalah pembelajar yang heterogen dan visual yang lebih mudah memahami bacaan berbahasa Inggris jika kebetulan konten itu berbasis gambar. Selain itu, Dari temuan studi ini dapat disimpulkan bahwa mahasiswa sangat memerlukan gambar pendukung untuk memahami teks prosedur berbahasa Inggris. Gambar-gambar tersebut dapat memacu kreativitas mahasiswa untuk merumuskan dan menjelaskan apa yang terjadi (Kasmaienezhadfard, Pourrajab, \& Rabbani, 2015). Mahasiswa akan merasa kesulitan jika penjelasan prosedur tidak disertai gambar. Kondisi 
tersebut dapat dilihat dari tanggapan salah satu mahasiswa:

$$
\begin{aligned}
& \text { "Karena dengan adanya gambar, saya } \\
& \text { dapat memahami maksud dan } \\
& \text { pengertian, jika ada tulisan dapat saya } \\
& \text { pahami juga namun kesulitannya jika } \\
& \text { ada kata yang asing bagi saya, saya tidak } \\
& \text { bisa langsung paham dengan maksud } \\
& \text { dan pengertian" }
\end{aligned}
$$

Dari jawaban salah seorang mahasiswa, hal tersebut menunjukkan bahwa sekalipun mahasiswa tidak mengerti beberapa kosakata bahasa Inggris, mereka akan bisa memahami maksud dan tujuan dari teks prosedur berbahasa Inggris yang disertai gambar sebagai ilustrasi.

Mahasiswa yang lain juga mengatakan:
"karena untuk gambar adalah cara paling ampuh dan mudah serta sederhana untuk mengerti apa yang ingin disampaikan tanpa seseorang harus menjelaskan terlebih dahulu, apalagi bagi orang yang tidak mengerti bahasa Inggris dengan menggunakan gambar dapat membantu seseorang mengerti apa yang ingin disampaikan."

Artinya sebagian besar sepakat bahwa pentingnya penyertaan gambar dalam teks prosedur berbahasa Inggris adalah visual untuk memudahkan memahami teks berbahasa inggris dan meningkatkan daya imajinasi dalam memahami bacaan tersebut.

Bahkan ada yang memberi pernyataan bahwa penjelasan dengan gambar sudah memadai dan tidak perlu memakai penjelasan menggunakan teks, seperti pernyataan:

"Menurut saya, karena hanya dengan gambar yang di[r]ubah ke layar itu sudah membuat orang mengerti apa yang sedang ada[teks]."

\section{G. Alat Penerjemah yang digunakan oleh Mahasiswa Vokasi}

Dalam memahami bahasa asing yaitu bahasa Inggris, mahasiswa perlu memakai suatu media penerjemahan. Google Translate menjadi pilihan mahasiswa vokasi untuk menerjemah bahasa Inggris.

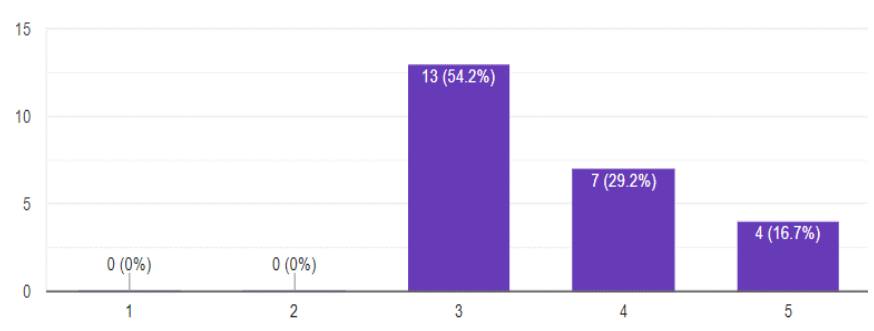

Gambar 6: Frekuesi Penggunaan Google Translate

Dapat dilihat diatas bahwa tidak ada yang tidak pernah menggunakan alat bantuan terjemahan Google. Bahkan $4(16,7 \%)$ orang selalu menggunakan Google Translate sebagai alat bantuan terjemahan. Banyak mahasiswa memilih Google Translate sebagai alat terjemahan karena Google merupakan platform terkemuka dan sangat mudah untuk digunakan. Bahkan Google translate selalu mengupdate basis datanya dengan meminta saran dari seluruh penerjemah di seluruh dunia.

\section{H. Kesulitan Mahasiswa dalam Memahami Teks Bahasa Inggris}

Kesulitan terbesar Mahasiswa dalam memahami adalah kurang menguasai kosakata bahasa Inggris, bahkan ada yang belum menguasai kosakata bahasa Inggris dalam bidang TI, seperti pernyataan:

"Belum menguasai vocabulary bahasa Inggris di bidang saya"

"Mungkin kesulitannya adalah pada saat menggunakan istilah-istilah bahasa inggris di dalam dunia TIK”.

"Sulit mengartikan kata-kata baru yang jarang $d$ jumpai dan saya masih memerlukan google translate untuk mengartikannya"

"Terkadang ada teks bahasa Inggris yang menggunakan vocab[ulary] yang lumayan jarang saya dengar atau saya baca. 
Pernyataan-pernyataan tersebut menunjukkan mahasiswa tersebut belum akrab dengan istilahistilah TIK dalam bahasa Inggris.

Disisi lain ada mahasiswa yang sudah familiar dengan istilah-istilah TI bahasa Inggris, namun jika teks prosedur yang bersangkutan adalah kalimat yang panjang, maka dia akan mengalami kesulitan dalam memaknai kalimat tersebut, sehingga mahasiswa tersebut membutuhkan Google Translate. Hal ini dipertegas dengan jawaban dari responden, yaitu:

"kesulitannya itu tidak mengerti artinya secara penuh, jadi saya harus mentranslate kan kalimat yang saya tidak mengerti."

Namun ada yang merasa sulit jika teks prosedur yang disajikan bukan mengenai dunia TI. Ada mahasiswa terbiasa dengan istilah di TI namun akan merasa kesulitan jika ditampilkan mengenai bidang keilmuan lainnya seperti yang diungkapkan oleh salah seorang mahasiswa:

"Tidak, jika dibahas tentang komputer tapi sangat sulit saya pahami jika membahas tentang lainya"

\section{KESIMPULAN}

Ada beberapa yang dapat disimpulkan setelah melihat hasil dari kuesioner yang dibagikan kepada mahasiswa vokasi TIK Politeknik Negeri Lhokseumawe (PNL) mengenai keberadaan gambar sebagai pendamping teks prosedur berbahasa Inggris yang ada di dalam buku bacaan, modul, atau bahan ajar dosen. Pertama, mahasiswa vokasi TIK PNL adalah pembelajar visual, dimana dengan adanya gambar akan membantu mereka dalam memahami teks bahasa Inggris. Hal ini dipertegas dengan temuan penelitian dimana hal pertama yang dilakukan oleh $66,7 \%$ dari mahasiswa ketika melihat langkah-langkah atau prosedur adalah dengan melihat gambar terlebih dahulu. Maka sangat diharapkan agar buku-buku, modul, dan bahan ajar yang berbahasa Inggris dimasukkan gambar-gambar langkah yang sesuai dengan teks berbahasa Inggris. Hal ini sesuai dengan harapan seluruh mahasiswa responden dimana mereka sepakat bahwa semua materi ajar harus disertai gambar. Namun gambar bukan semata-mata yang diperlukan, teks juga masih diperlukan oleh mahasiswa dalam memahami rangkaian prosedur di dalam materi ajar.
Untuk teks sendiri, mahasiswa tidak sepenuhnya memahami. Ada kosakata-kosakata yang tidak pernah mereka dapat bahkan di bidangnya sendiri. Selain itu jika pun mereka dan akrab dengan kosakata-kosakata bahasa Inggris tersebut, mereka juga akan kewalahan menerjemahkan secara keseluruhan jika ada kalimat atau frasa yang utuh.

Media penerjemah yang digunakan untuk membantu para mahasiswa adalah Google translate. Semua mahasiswa pernah menggunakan google translate,namun mereka masih tetap membutuhkan gambar dan penjelasan dosen mereka sendiri.

\section{REFERENSI}

Bire, A. L., Geradus, U., \& Bire, J. (2014). Pengaruh gaya belajar visual, auditorial, dan kinestetik terhadap prestasi belajar siswa. Jurnal Kependidikan: Penelitian Inovasi Pembelajaran, 44(2).

De Porter, B., \& Hernacki, M. (2000). Quantum learning: PT Mizan Publika.

Harmer, J. (2007). The practice of English language teaching. Harlow. England: Pearson Education.

Hestri, S. (2013). The Effectiveness of Using Picture Series to Improve Students Writing Ability in Recount Text at The Eight-Grade Students of SMPN 33 Purworejo in The Academic Year of 2011/2012. SCRIPTA - Pendidikan Bahasa Inggris(Vol 1, No 2 (2013): English Research Articles).

Hidayah, N., \& Hermansyah, F. (2016). Hubungan Antara Motivasi Belajar Dan Kemampuan Membaca Pemahaman Siswa Kelas V Madrasah Ibtidaiyah Negeri 2 Bandar Lampung Tahun 2016/2017. TERAMPIL: Jurnal Pendidikan dan Pembelajaran Dasar, 3(2), 87-93.

Houghton, C., Murphy, K., Shaw, D., \& Casey, D. (2015). Qualitative case study data analysis: An example from practice. Nurse researcher, 22(5).

Huberman, A. M., Miles, M., \& Saldana, J. (2014). Qualitative data analysis: A 
methods sourcebook. The united states of America: SAGE publications.

Kasmaienezhadfard, S., Pourrajab, M., \& Rabbani, M. (2015). Effects of pictures in textbooks on students' creativity. Multi Disciplinary Edu Global Quest (Quarterly), 4(2), 14.

Masykar, T. (2019). Analisa Kebutuhan English for Specific Purpose untuk Pendidikan Vokasi. VOCATECH: Vocational Education and Technology Journal, 1(1), 47-50.

Masykar, T., \& Nurrahmi, F. (2020). Motivation and satisfaction towards two-year vocational diploma. Jurnal Pendidikan Vokasi, 10(1).

Maulida, H. (2017). Persepsi Mahasiswa Terhadap Penggunaan Google Translate Sebagai Media Menerjemahkan Materi Berbahasa Inggris. Jurnal SAINTEKOM(Vol 7 No 1 (2017): Maret 2017), 56-66.

Rosyada, A. (2018). Improving Students Critical Thinking to Develop Variety Essays through Picture Word Inductive Model. UICELL(No 2 (2018): UICELL Conference Proceedings 2018), 50-57.

Sa'diyah, Z. (2014). Tipologi Kesalahan Kebahasaan dan Keakuratan Hasil Terjemahan Google Translate Teks Bahasa Indonesia ke Dalam Bahasa Arab. Arabia(Vol 6, No 2 (2014): JURNAL ARABIA).

Saputro, Y. (2013). Teaching Preposition by Using Illustration Picture as The Media for The First Year Students of MTS HS Wadaslintang in The Academic Year of 2012/2013. SCRIPTA - Pendidikan Bahasa Inggris(Vol 2, No 3 (2013): English Research Aritcles).

Tama, S. A. (2014). The Impact of Using Pictures on the Students Vocabulary Mastery at Grade Three of SD Negeri 2 Rulung Raya Natar South Lampung in Academic Year 2013-2014. International Conference on Education and Language (ICEL)(Vol 2 (2014): 2nd ICEL 2014).
Widyaningrum, L. (2014). The Effect of Using Pictures on Students Speaking Ability at Grade Eight of SMPN 2 Seputih Mataram Lampung Tengah. International Conference on Education and Language (ICEL)(Vol 2 (2014): 2nd ICEL 2014).

Wright, A. (1989). Pictures for language learning: Cambridge University Press. 

This works is licensed under a Creative Common Attribution-ShareAlike 4.0 